\title{
Recent Experiences of Stabilisation: Argentina's Economic Policy 1976-81*
}

\section{Luis Beccaria and Ricardo Carciofi}

'This (the fact that "the causal chain between money and incomes or money and prices is the reverse to that postulated by the Quantity Theory of Money") does not mean that a "monetarist" economic policy such as that of the present government is futile... Control over the "monev supply". which has in any case been ineffective on the government's own criteria, is no more than a convenient smoke-screen providing an ideological justification for such antisocial measures (high interest rates, an overvalued exchange rate and the "consequent diminution in the bargaining strength of labour due to unemployment"l).

|Lord Nicholas Kaldor 1980; emphasis added.|

\section{Introduction}

As pointed out by modern economic textbooks, specialised journals and newspapers, 'monetarism' is an economic doctrine that has been gaining world wide diffusion over the last ten years.' Several circumstances explain its increasing popularity: the collapse of the international monetary system established in Bretton Woods, the lack of coordinated expansionary policies (inspired by Keynesian principles) pursued by major industrial countries, disturbances associated with the instability of world prices as a result of oil inflation, etc. All these factors are international in character and intricately inter-related. Their overall outcome is so complex that many economists and politicians have begun to designate the 1970 s as a decade of crisis in the world economy. Monetarism is, in fact, an attempt to provide a response to this international situation. And both features - the diffusion of monetarism and the world crisis - are twin phenomena because the economic theory of monetarism extracts its main strength from simplicity of formulation: the theory purports to be a simple (and radical) way out of today's international problems.

\footnotetext{
*A shortened and revised version of Economic Policy in Argentina after $1976^{\circ}$. originally presented at the Cambridge Journal of Economics Conference on the New Orthodoxy in Economics held in Cambridge. UK in June 1981. In preparing the current version the authors have benefited from discussions and comments made by the participants at that conference. Useful suggestions by the editors of this issue of the IDS Bulletin are also acknowledged. Recognition of I hese cont ributions does not implicate any of the persons involved.

'The statement paraphrases the widely known monetarist dictum that inflation always has a monetary character. When stated in those terms. the proposition is tautological. The crucial question is to know whether there is a one-way relationship between money and income. On this point. see Kaldor | 1970 .
}

According to this doctrine, capitalist economies are remarkably stable in their behaviour. Furthermore, monetarism tends to locate the causes of all difficulties in too much state intervention and misleading political promises of full employment. It is said that inflation, or even worse, stagflation, is the price that modern economies are paying for achieving conditions of 'ephemeral' prosperity built upon weak economic bases. The appealing simplicity of this diagnosis is extended to economic policy making. 'Inflation (and stagflation) is always and everywhere a monetary phenomenon' which requires monetary remedies. ${ }^{2}$ According to this approach Central Banks are allpowerful institutions; they 'control' the quantity of money that exists in the economy and it is precisely sober management of the money supply that is the key to price stability.

However, as the quotation from Lord Kaldor above suggests, these (monetary) remedies are neither economically cheap nor socially desirable. Monetarist policy makers are fully aware of these implications and usually claim that only sensible (and strong) governments can consistently implement monetary control: real cures can only be wrought by bitter remedies, and the only contribution the patient should make is a quota of courage to undergo the treatment. Putting analogies aside, it has also become fashionable to answer criticisms levied against monetarist policies by pointing out 'successful cases' where governments have not hesitated to apply healthy monetary control despite certain 'short-term' socio-economic costs | see McKinnon on Díaz Alejandro 1981 I. Until recently, the Chilean experience after 1973 was often quoted as a 'successful case'.

Unfortunately, cases of monetarist failure are less widely known, despite the fact that these experiences are of no less intrinsic value. The following discussion attempts to compensate for this imbalance by analysing monetarist policies applied in Argentina between 1976 and 1981. The main contention is that these policies may not constitute a valid solution for semi-industrialised economies that have gone through a significant process of import substitution, even when those programmes are backed up by political regimes whose modus operandi do not raise any doubts about their commitment to an authoritarian state.

\footnotetext{
'See. for example. the recent symposium on monetarism organised by The Economic Journal and. in particular. the paper by Tobin | 1981 | presented at that symposium.
}

Bulletir. 1981, yol 13 no 1. Institute of Development Studies. Sussex 


\section{Monetarism as a Strategy of Economic Development}

Economic theories and their derivative policies do not convey the same message in different social contexts. The sharp disagreement between Keynesians and monetarists revolves around the best policy instrument to 'stabilise' industrialised economies where no major structural problems exist ${ }^{3}$. In the case of developing countries the term 'stabilisation' is totally inadequate to describe the operation of the economic policy. What is at stake here is not the control of a certain level of aggregate demand and domestic inflation, but rather a more comprehensive procedure to speed up the pace of capital accumulation of those societies and to set up the basis of industrial growth. Economic policy-making in that context is, in fact, an overall strategy which makes use of several policy instruments to transform the nature of the society. And the real difficulties of deploying a certain economic strategy in semi-industrialised countries are not related to problems of implementation; the central question is to know whether or not the ruling classes of that society will be able to retain control of economic policy so as to shape the productive structure according to their intentions. This process implies both a successful internal class alliance and a viable integration of the domestic economy into the world market.

An important pre-condition of that development is the role of the state, since access to it becomes necessary in order to design economic policy. It is for this reason that development policies in semi-industrialised countries favour an active state role, and fiscal and monetary policy are not just countercyclical devices, as assumed in macroeconomics textbooks. On the contrary, economic policies make intensive use of fiscal and monetary instruments to establish a certain process of accumulation. This interventionist character is based upon the belief (and historical evidence supports this) that development of semi-industrial economies does not automatically follow the operation of market forces. It may be concluded that notions based on a belief in the intrinsic stability of the market - as argued by the monetarists--imply not just a different policy for dealing with the trade cycle but rather a different strategy to tackle the development of peripheral societies.

The Argentine experience fits, in general terms, into the mould described above. After a period of 50 years (1880-1930) of the successful operation of an exportled rural model, the country attempted to develop an industrial structure based upon a policy of import substitution. Tariff protection, credit subsidies, exchange

The statement should be understood in relation to the situation faced by ldes. It is far from our intention to argue that indust rially developed economies are free from difficult problems that may threaten their possibilities of long-term growth. The present conjuncture faced by the UK economy is a good example. rate management, fiscal policies and control of domestic rural prices allowed a significant expansion of light industries and consumer goods sectors. Industrial development began to encounter several difficulties in the mid-1950s as it became increasingly difficult to expand the internal market, and the access of nontraditional exporters to the world market was barred because their costs were off the international competitive line. As a result the late 1950 s and early 1960 s was a period of 'traumatic' economic growth: balance of payments restrictions imposed an upward limit to domestic expansion on several occasions; stop-go cycles within an inflationary context were frequent and the country suffered IMF deflationary programmes on several occasions | see Díaz Alejandro 1970|. Foreign capital and substantial income transfer devoted to export promotion, and social pacts backed up either by weak political alliances or authoritarian military governments helped shift outwards the external restriction and fostered industrial growth. The model turned out to be unworkable in the early 1970s.

The industrial groups that were leading the process of opening up the economy and promoting new sources of investment lost control of the state apparatus. Urban groups composed of powerful trade unions and industrial capitalists regained influence over economic policy and attempted to increase their share in the national income. Between 1973 and March 1976 economic growth was based upon the expansion of consumption through an incomes policy whereby unions were able to obtain favourable terms for their members. Wages went up and, therefore, industrial production of consumer goods went up as well [Canitrot 1975]. The improvement of profit margins of wage goods sectors and the distribution of incomes towards wage earners associated with it did not last very long. As was the case in the earlier crises of the 1950s and early 1960 s, the expansion of the internal market clashed with the limits imposed by the balance of payments. The result was not entirely unexpected; another military government took power with the purpose of implementing a deflationary policy in order to eliminate the enormous discrepancy between overall supply and demand that the Argentine economy was suffering at that time.

There was, however, a basic difference between the situation of the mid-1970s and previous critical conjunctures of inflation and balance of payments disequilibrium. The social outcome of three decades of import-substituting industrialisation was an increasingly difficult political situation where military governments controlled the social behaviour of urban workers and fractions of the industrial bourgeoisie that were not reaping the immediate benefits of econonic expansion. Attempts at resisting authoritarianism and relaxation of political conditions which surrounded 
that mode of economic expansion led to outbreaks of civil war and subsequent military coups. But in one way or another the different military interventions that took place after the mid-1950s had the explicit purpose of tightening internal consumption, and favoured the expansion of industrial investment.

However, the military authorities who seized power in March 1976 made a different diagnosis. According to their interpretation, the clearest (although extremely negative) consequence of state-managed industrialisation was a series of social and political conflicts that threatened the institutional stability of the system. What was needed above all was the 'restoration of order'. In equating protected industrialisation with social chaos, the alternative way out was also clear; dismantling the structure of protection and the instruments of industrial promotion would (almost automatically) generate the basis of a less conflictridden society.

The political situation and the military forces' diagnosis did not lack their respective rationalisations at the level of economic policy. Monetarist views and their theoretical Walrasian foundations fitted nicely with the stance adopted by the military. On the one hand, inflation could rightly be attributed to large fiscal deficits; from this was deduced the need to curb the gigantic state. On the other, the slow rates of economic growth of Argentina's post import-substitution period were attributed to too much state intervention; market forces had ceased to fulfil their allocative functions and the consequences were apparent. Protected industrialisation had been a mistake, bringing a long period of inefficient economic growth. Efficiency ought, therefore, to be achieved by restoring the operation of the market. On these grounds too, the economic policy encouraged a reaction against the period of industrialisation and its associated instruments of promotion. In sum, monetarism represented a convenient smoke screen to launch a strategy that attempted to alter the path of development that began almost simultaneously with the process of import substitution.

\section{The Implementation of the Programme}

Locating economic policy in the global context discussed above helps us to understand the constraints on the pace of implementation of the programme. At the time of the coup, the new government faced a situation of near hyperinflation (beginning in mid-1975) with prices soaring at a monthly rate of about 20 per cent ${ }^{4}$. There was also a very low level of foreign reserves and a large balance of payments deficit ${ }^{5}$. The fiscal deficit

\footnotetext{
${ }^{+}$The rate of inflation during the four months previous to the coup was as follows: December 12\%; January 15\%; February $29 \%$ : and March $38 \%$

The level of reserves of the Central Bank was $\$ 0.7$ bn but external reserves of free availability were approaching $\$ 20 \mathrm{mn}$.
}

was running at over 15 per cent of GDP. Despite the fact that 1975 had been a year of negative growth $(-0.9$ per cent $)$, built-in inflationary pressures suggested that the programme had to begin by applying further deflation. However, the government was not just committed to controlling inflation for its own sake: it regarded inflation as the negative consequence of deeper causes that had to be cured if economic growth under conditions of price stability was going to be achieved.

This meant that the programme had to deploy a twopronged strategy. On the one hand, there was a set of structural transformations associated with the role of the state and the instruments traditionally used to promote industrialisation. In this sense the target was to shrink the state apparatus and re-create market mechanisms within spheres previously under direct state control. On the other hand, there was the compelling necessity to bring inflation under control and deal with the short term behaviour of the economy in order to arrive at satisfactory results in that area.

The initial conditions of the programme and its longterm targets led to an immediate linkage between the anti-inflationary battle and the overall performance of economic policy. Insofar as the history of Argentina's industrialisation had been a long inflationery experience, the evolution of the price index would be the yardstick of success. A reduction of the inflation rate would mean that the economy was closer to starting a new model of growth based upon more healthy foundations. By the same token it implied that anti-inflationary policy was allowed to try different combinations of instruments to deal with price increases, as these rates were the indicators that justified the application of the economic policy as a whole. Furthermore, the design of the anti-inflationary policy was to be adjusted according to the new (and different) tools of management of the economy put in the hands of the government by the programme of structural change.

\section{Structural Change and the Foundations of the New Economy}

The move towards dismantling the mechanisms of industrial promotion led to a concentration on three major policy areas: tariffs and the foreign exchange market; the role of financial institutions and the organisation of the money market; and, the redefinition of the functions and size of the state.

In relation to the first issue the objective was to reduce tariff protection levels. (The nominal average rate for industrial products was 95 per cent when the economic team took office.) There was no long term plan of reduction from the outset; during the first three years of the economic programme tariffs were cut down at random intervals locating the average at around 40/45 per cent in December 1978. At that time a tariff 
reduction programme was announced and its target was to bring down the level of nominal protection to 20 per cent on average in $1984^{6}$.

Foreign exchange markets were liberalised faster than imports. First, the government abolished exchange controls which were particularly restrictive in the purchase of foreign currency. Second, the system of multiple exchange rates was eliminated. Third, the government sought the development of a floating exchange rate market with minimum Central Bank intervention. The first measure was promptly decreed in April 1976; despite scarcity of foreign reserves at that time elimination of exchange controls was not a problem to the extent that a massive devaluation avoided speculation against the peso? The unification of the foreign exchange market took place in November 1976; the government encountered several difficulties in operating a floating system.

It is interesting to compare the government's approach to the management of the external side of the economy with other policies aimed at promoting industrialisation. There is a relatively wide consensus that the Argentine economy suffered from excessive protection and that it had to be opened up to foreign competition. The problem is the procedure through which the industrial structure is exposed to foreign competition. Previous attempts had carried out strategies aimed at opening up the economy by starting the whole operation the other way round; in these cases domestic production is increasingly shifted towards the world market /Canitrot 1980|. And to the extent that it was necessary to compensate productivity differentials of the industrial sector vis-à-vis the rural sector, mechanisms of export promotion had been set up. That meant multiple exchange rates, credit subsidies, tariffs and draw backs, etc. After the 1976 coup, the government's long-term strategy for opening up the economy meant exactly the opposite; the domestic market begins to reflect world prices and they represent the 'signals' for transforming the productive structure. It is for this reason that tariff protection should be cut down. What the government did not take into account was the fact that tariff reduction might be an adequate policy if (and only if) the set of prices of the economy (and in particular the rate of exchange) is located at

"It should be noted that the first stage (1976-78) of the process of tariff reduction did not have a significant impact upon the industrial structure. There are two factors that explain this outcome. In the first place it seems that the government's decision eliminated the margin of excess protection that was not used by domestic producers. Second. according to different calculations of purchasing power parity, the peso would have been undervalued during these two years and. as a result. foreign competition did not represent a real threat for domestic producers. IOn the policy of tariff reduction. see Sourrouille 1981. chapter II.

Official rates of exchange were increased by $100 \%$ locating the new levels at values closer to those registered in the non-controlled market. (Exchange rate is defined here as the price in terms of pesos for a unit of foreign currency.) equilibrium levels ${ }^{\star}$. This condition is exceedingly difficult to fulfill in an inflationary economy like Argentina where changes of relative prices are drastic and frequent. In other words, the government's strategy of opening up the economy would imply a cost for the industrial sector in that the economic policy was not able to guarantee an equilibriated structure of relative prices. In fact, as will be discussed below, the actual outcome was even worse because the government relied upon tariff reduction and the exchange rate to control domestic inflation.

Another structural change was financial reform. The new system implied a shift towards a free market where the criteria to regulate the interest rate were liberalised. The decision implied a sharp break with the traditionally Central Bank-determined interest rate system applied since the mid-1940s. Similarly, the law restored to the banks and non-bank intermediaries the capacity to allocate credit assets according to their own criteria. During the previous government, the Central Bank had assumed the function of management of credit policy, and, supposedly, financial institutions depended directly on the Bank. This centralised financial policy was never actually put into practice ${ }^{y}$. Nevertheless, the new law restated the legal abolition of the old regime.

The financial reform had two important implications. First, the domestic money market was opened up to foreign competition. To achieve this, the government made every possible attempt to eliminate restrictions on capital movements and to equalise domestic and external borrowing costs. Second, as a result of interest rate liberalisation, state-owned banks gave up their policy of promotion of rural and industrial activities. Again, the new guidelines for credit policy for development banks meant a different notion of the functions that those institutions should perform. Since their creation in the mid-1940s these banks were committed to supporting productive investment and making funds available for special projects.

In relation to the role of the state, the basic idea was the so-called 'subsidiary principle'-ie, the state should lay the basis for economic activity but should not actively intervene in any way that precluded the operation of the private sector. However, policies aimed at reducing the absolute size of the state machinery were not very successful. In fact, during the five years of the economic programme, public investment (as a percentage of GDP) was at the highest point of the whole decade. The economic difficulties that faced the government in that area were closely linked to previous decisions and political aspects. On the one

"If that condition is fulfilled. free trade theorems demonstrate that tariffs represent a reduction of welfare and losses in production.

${ }^{4}$ Deposits had been nationalised during the first period of importsubstitution (1945-55). 
hand, the programme of Public Works had already started when the economic team took office in 1976 and there were serious technical difficulties in halting projects. On the other hand, the outbreak of conflicts with Chile on problems of border demarcation led to a costly programme of military expenditure.

Nevertheless, the implementation of the 'subsidiary principle' was more effective in other areas. For many years different economic policies had implemented different measures of price control or price guidelines for the private sector as a way of putting a brake on the inflationary pressures that made the operation of incomes policies difficult. Disregarding price and income distribution consequences, the 1976 economic programme decreed a thorough price liberalisation, thereby assuming that anti-inflationary policy could not be mounted on principles that contradicted the theoretical premises of the plan.

An extension of this view was also applied to the labour market. There was military intervention in unions, the right to strike was abolished, and the government began to prepare a new bill to modify the structure of trade union organisation.

Apart from these moves towards liberalisation of the economy there were other measures of a structural character. For example, the government decreed a new legal framework for foreign investment. The new bill granted more favourable conditions of profit transfer, depreciation of investment and exemption from foreign exchange controls, even during situations of Central Bank's reserve emergency. Trade liberalisation and the law seeking to attract foreign investments were not enough. Financial flows were mainly restricted to short-term operations which responded quite elastically to differences in interest rates. These poor results are not surprising since a large portion of foreign capital invested in Argentina during the late 1950s and early 1960s had the explicit purpose of orienting its production towards the internal market and gaining from tariff protection. Thus, the economic strategy conflicted with the interests of long-term foreign investors.

\section{Stabilisation policies}

In analysing government strategy on short-term problems, it should be recognised that, in fact, several strategies were implemented over the five years under review. As explained above, the high rate of inflation meant that policy was directed towards bringing price rate increases down.

\section{Traditional policies of external and internal adjustment}

During the first two years the authorities followed a set of policies resembling typical IMF stabilisation packages. Over the next two years, the economy witnessed the implementation of a policy whose monetarist underpinnings along the lines of the new orthodoxy are so clear that it makes Argentina a textbook case.

The stabilisation programme launched immediately after the 1976 coup attempted to build up the exhausted stock of foreign reserves and to halt the runaway inflationary process. It was composed of a set of measures that pushed down aggregate demand through nominal wage freeze and, additionally, eased the balance of payment deficit by encouraging rural exports.

Given the structure of the Argentine economy, it is not very difficult to improve, quite quickly, the shortterm evolution of the external side of the economy. The control of inflation is a more complex task. Exchange rate devaluation immediately takes incomes away from the urban groups and transfers them to the rural sector. This measure also produces a substitution effect that speeds up external adjustment. At the same time, devaluation implies a higher absolute (and relative) level of rural prices that reduce real wages (if nominal wages are kept constant), thereby triggering off a declining trend of internal consumption and increasing exportable rural surpluses. Lower levels of consumption have, in turn, an indirect (and beneficial) effect on the import bill because it diminishes the demand for imports. In all likelihood, if political conditions can sustain the reduction of real wages, the balance of payments gets under control. There has been, however, some controversy as to whether devaluation and nominal wage control is enough to beat inflation. While some authors argue that devaluation deflates the overall level of economic activity, others suggest that these measures should be applied with a restrictive monetary policy [Díaz Alejandro 1965, 1970; Sidrauski 1968].

The actual outcome of the 1976 devaluation was undoubtedly successful in terms of balance of payments, although it had mixed results in terms of output. Price effects associated with devaluation and falling internal consumption allowed imports to fall. A record harvest pushed up exports and the current account was, in consequence, rapidly controlled. Output fell during $1976(-1.7$ per cent $)$ although it began to recover in the last quarter of that year and followed an upward trend during 1977 (4.9 per cent). As a result the government found it difficult to put an effective brake on inflation. Furthermore, during the last two quarters of 1977 short-term capital inflows flew into the country, attracted by high nominal interest rates (interest rates began to go up after the liberalisation of the money market).

This meant that even within an excess aggregate demand' diagnosis the economic policy of the first two 
years did not apply strong deflationary shock treatment, as was the case of previous stabilisation packages implemented in Argentina during the early 1960s. These results were not those desired by the government; its room for manoeuvre was constrained by external and internal factors. On the one hand, international liquidity made available finance that could be used by borrowers with access to external credit. On the other hand, there were many internal restrictions: it was impossible to cut down the fiscal budget to a level compatible with the reduction of inflation; sweeping devaluation put a considerable distance between foreign competitors and local (industrial) producers who were able to increase domestic prices even when tariffs were being reduced; and, finally, there was a clear political decision not to increase unemployment [Beccaria 1980].

The relatively successful performance of economic policy in terms of external equilibrium and the evolution of domestic output was, however, a source of permanent difficulties on the inflation front. Between mid-1976 and the third quarter of 1977 prices were rising at an average monthly rate of eight per cent. This figure represented an improvement in relation to the evolution of prices over the last months of the previous government, but this lean victory could not be considered an adequate basis for stable economic growth. As a consequence, the economic team began to develop specific anti-inflationary instruments.

A first attempt was made in the last quarter of 1977 , when the Central Bank decided to tighten up the expansion of domestic credit. The problems created by the budget deficit were solved through cutting off Central Bank financing of the public sector. PSBR began to be covered by Treasury bills sold to the public, and the demand for finance raised by deficit public enterprises was also channelled to the domestic (and external) money market. The effects of monetary policy upon interest rates were impressive. During the first quarter of 1978 the rate of interest paid by borrowers climbed to 14 per cent per month. For the first time the Central Bank and its policy of traditional credit restriction was putting up nominal interest rates at a level which was positive in real terms (between January and March 1978 prices were increasing at a monthly rate of 8.6 per cent). Monetary policy also made a drastic impact on the level of economic activity. (Between the last quarter of 1977 and the first of 1978 industrial GDP fell by 25 per cent -the most drastic recession since 1950, at least.) Despite output consequences, prices did not go down. In fact, monthly rates increased over and above the eight per cent already mentioned that prevailed during 1976 and the first three quarters of 1977. Stubborn inflation may be explained by the fact that domestic producers were attempting to resist high nominal interest rates via price increases (in order to diminish real financial costs). In turn, the increasingly difficult access to internal bank credit was being offset by the supply of money coming from the international market.

\section{Global monetarism}

In April 1978 the authorities decided to avoid the disturbing effects associated with inflows of shortterm financial capital. In fact, what they did was to 'correct' certain inconsistencies of implementation of the monetary policy applied by the Central Bank. During the period of tight money supply the Bank had been managing exchange rates and domestic credit. Obviously, this conflicted with the monetarist premises that informed the new economic policy. (According to the monetary approach to the balance of payments the authorities should control either the money supply - allowing a free floating of the exchange rate-or the exchange rate, where the money supply becomes an endogenous variable [Johnson 1978]. In order to make the model consistent, the Central Bank chose on this occasion to control the money supply, and decided not to intervene on the foreign exchange market. In practice their policy was different. The extremely favourable reserve position and the evolution of the current account made free floating very difficult. The government feared the drastic appreciation of the peso that might emerge as a by-product of these measures. Consequently, the Central Bank did not give up its intervention on the market, allowing a further increase in external reserves. Additionally, the Bank decided to tax the inflow of foreign capital in order to discourage borrowing from abroad and to flatten out pressures that would end up by appreciating the peso. Between April and December 1978 the Central Bank succeeded in slowing down inflows of foreign capital to a certain extent. But domestic prices increased more than the rate of devaluation, thereby appreciating the peso; this, together with the high interest rates that prevailed in the domestic money market, offset the extra costs imposed by taxes on foreign borrowing. The government faced yet another failure of the stabilisation programme; the opening-up of the internal financial market within an extremely liquid international context led to an expansionary monetary policy. Effective control of inflation could not be implemented through tight money supply and high interest rates, unless foreign exchange intervention allowed a substantial revaluation of the domestic currency in order to increase imports and competition from abroad.

In December 1978 the government embarked on a new anti-inflationary plan. As in Chile, the rate of exchange was used as a tool to shape the behaviour of domestic prices. The nominal rate of exchange was fixed in advance. In practice, the Central Bank 
announced a monthly rate of devaluation for the next months. The theory was as follows: as the exchange rate becomes the guideline for domestic pricing, devaluation declines towards zero. At that point internal inflation equals international inflation. The main requisite of the strategy is that domestic producers are "locked in' by foreign competition. If they increase their prices over and above the announced devaluation rate, national currency appreciates and, as a consequence, imported products become cheaper, thereby cutting demand for domestic output. This substitution effect is the essential weapon that helps to control internal prices.

This package implied a shift towards a fixed exchange rate system where the Central Bank lost control over the total stock of money in the economy. Within this monetary approach to the balance of payments the Central Bank has, in a small open economy, very limited possibilities of controlling interest rates, since they reflect international rates (plus or minus risk differentials).

The degree of success of a programme of this sort depends on several factors. First, foreign goods can help to control domestic inflation if consumers have almost perfect access to them. The programme will have stabilising results only insofar as domestic products are not competitive once their prices grow faster than the devaluation rate. However, there are difficulties in fulfilling this especially during the initial stages of the programme. The Argentine economy has been relatively closed to foreign competition for quite a long period. The structure of commercialisation necessary to make imports available takes some time to develop; in the meantime local producers do not face actual competition from abroad. Furthermore, to the extent that stabilisation favours trading in foreign products many producers may find it profitable to become importers. As a result, they can have access, at least temporarily, to oligopsonist positions that preclude prices from falling as expected.

The second condition of success is that there must not be excess tariff protection. If, by any chance, there is some margin in the tariff structure, local producers will use that margin of excess protection to increase prices. Tariff reductions applied in Argentina during the first two years of the plan led the government to think that this was not the case, and that the industrial sector as a whole was on the borderline of foreign competition.

Another element that makes the adjustment process more difficult derives from the fact that exchange rate changes do not convey the same anti-inflationary guideline for all producers; production of non-traded goods is subject to no foreign competition and, therefore, the pricing behaviour of this sector may prove quite stubborn. The stabilisation plan may be effective in controlling prices of traded goods whereas it has limited room for manoeuvre in relation to non-traded goods. If that is the case, the period of adjustment will imply a shift in relative prices in favour of non-traded goods simply because the stabilisation programme is unable (or less able) to deal with them.

Monetarist policy makers who supported the plan responded to problems created by differential speed of adjustment by negating its actual validity. The argument was theoretical and derived, again, from the premises of the whole plan. According to them, if nontraded goods are inflationary-ie shifting relative prices - that process would in itself generate differential profitability in that sector of the economy and would end up by increasing supply and reducing prices.

On the whole, it seems that policy makers believed not only that capital mobility between sectors was almost instantaneous, but also that the other conditions for a successful stabilisation programme would easily be fulfilled. In sum it was the economy that had to adjust to the predictions of the theory; the relevance of the latter was obviously out of the question.

The results were however disappointing. Those sectors which faced foreign competition and the rural sector suffered a profit squeeze, as their prices were actually slowed down via exchange rate management. Some traded goods producers for whom threats from imports were not effective and non-traded producers as a whole did not find it difficult to increase prices faster than the devaluation programme. During 1979 inflation remained at 150 per cent (showing almost no change over the previous year) and there was an expansion of real output (6.5 per cent). This 'unstable economic growth' was being financed by foreign lenders. To the extent that they knew that the authorities were committed to a pre-announced exchange devaluation programme, there were no risks in investing financial capital in Argentina. Rather, the real appreciation of the peso that the economic policy was producing made it an excellent choice. These trends (and speculative attitudes) showed a drastic reversal in 1980. The strategy of cheap foreign currency was producing an enormous deterioration of the current account. Foreign investors began to expect future devaluations and this triggered off capital outflows. The Central Bank attempted to offset the higher risk prime by increasing domestic interest rates. During the first half of 1980 this measure succeeded in avoiding drastic outflows, but during the last two quarters speculation against the currency put even more pressure on interest rates. As recognised by the authorities themselves, it seemed that the Central Bank was ready to accept any costs in terms of interest rates to put a brake on speculation. Global out put remained stagnant 
during 1980 and inflation slowed down (90 per cent). However, these results were achieved at a very high cost: recession in the industrial sector, a massive invasion of imported goods of all kinds and unbearable pressure upon Cental Bank reserves. The significant real appreciation of the peso over 1980 and the internal opposition to the policy of active crawling peg made devaluation inevitable. Foreign investors anticipated these measures and the demand for external reserves increased sharply during January and February 1981. The stabilisation programme was abandonned in March 1981; a new economic team and a different economic policy has started since. The initial measures were devaluation and restoration of multiple exchange rates. The programme has encountered many difficulties deriving from the effects of the previous economic policy. Nevertheless, the question has now changed: which instruments are used to restore the capacity of accumulation within the industrial sector after five years of sustained attempts to set up the basis for 'noninflationary economic growth"?

\section{Concluding Remarks}

In trying to give an overall view of the Argentine experience between April 1976 and March 1981 it is necessary to stress the unifying concept that inspired economic policy over this period. The basic strategy that the government attempted to develop over these years was that the leap towards industrial maturity had to be guided by an efficient set of prices. To achieve that target the economic programme needed to recreate market mechanisms, to reduce state intervention, and to open up the economy to foreign competition. The first two years of this economic policy can be viewed as choosing the instruments, the necessary reforms and, above all, the general principles that would inspire the long-term goals of the govenment. By the first quarter of 1978 the economic policy looked as if it were a true representation of the old aspirations of the rural sector that attempted to move the whole economy back to the 1930s. The second stage (1978-81) of more consistent monetary management proved that the government had decided to sacrifice the profitability of the rural sector in order to dismantle the 'inefficient' industrial structure that had grown up during the period of import substitution. However, there is neither contradiction nor opposition between one stage and the other; despite different approaches to stabilisation policies the economic policy never experienced a ' $U$ turn' in its philosophy. The same targets were pursued over the five years although the instruments managed by the government were chosen according to the possibilities offered by the programme of structural reforms.

This raises two closely related issues: the first is the policy of trade liberalisation; the second, the crucial matter of political (and economic) support for the programme.

If one compares long-term targets and instruments it seems surprising that the government began to apply a firm policy of tariff reduction and foreign competition as late as 1978. If the achievement of an efficient constellation of prices was so important to the real success of the government's programme, why did it not adopt a faster process of trade liberalisation? In the first place it may be argued that the authorities decided to await the responses of the economy to the first stage of the stabilisation programme, the consequences of the financial reform and the early programme of tariff reductions (October 1976). One can imagine how the effects of this first stage could be used as an indicator of the type of adjustments that the programme needed in order to be totally effective. In this sense, the government adopted a cautious attitude, although this is not the explanation given by the economic team. In its opinion, the policy was 'gradualist'. And the appeal to gradualism does not imply a concession for a better adjustment to the policy by the private sector but rather that the social climate that surrounded the military coup of 1976 did not allow for further conflict with the industrial bourgeoisie. The political counterpart of the first stage of the economic policy was a bitter and an almost overt civil war in which the military forces were trying to keep institutional order under control. Obviously, this was an extremely unsuitable environment in which to launch a drastic trade liberalisation strategy.

Having taken into account these elements it is possible to take up the issue of the support to the programme. How is it that the Argentine bourgeoisie accepted the costs implied by the 1976-81 economic policy? As the social and political picture of the mid-1970s seemed to be on the verge of collapse, the industrial bourgeoisie and the rural sector as a whole did not hesitate to provide political support to a military coup that would help to preserve their more fundamental interests. Furthermore, to the extent that political reasons precluded the government from making its trade liberalisation strategy explicit, industrial capitalists believed that, at the end of the day, the economic policy would swing in their favour. The stabilisation programme applied between 1978 and 1981 proved that they were wrong. As this policy implied tariff reduction and currency appreciation that began to damage the concrete interests of the ind ustrial bourgeoisie (and the rural sector as well), massive opposition to the programme began to gather strength. Stubborn inflationary behaviour over the last two years is a clear indicator of that opposition. If Argentina had had a less developed industrial structure, the stabilisation programme would have had a higher probability of success. 
Finally, global analysis of the whole period suggests that the government was able to calculate the degree of conflict with different economic interests because, in fact, the policy was representative of none. The monetarist experience carried out in Argentina between 1976 and 1981 was a useful instrument of a military class that thought that the real causes of social disorder lay in successive attempts at 'inefficient' industrialisation. In sum, monetary control represented, in this case too, 'a convenient smoke-screen providing ideological justification' for putting forward an authoritarian strategy of transformation of the country.

\section{References}

Beccaria, L, 1980, 'Los movimientos de corto plazo en el mercado de trabajo urbano y la coyuntura 1975-78 en la Argentina: Desarrollo Económico, vol 20 no 78 , juliosetiembre

Canitrot, A., 1975, 'La experiencia populista de distribution de los ingresos; Desarrollo Económico, no 59, octubrediciembre

- 1980, 'La disciplina como objetivo de la politica económica. Un ensayo sobre el programma económico del Gobierno Argentino desde 1976; Desarrollo Económico, vol 19 no 76 , enero-marzo
Carciofi, R., 1981, 'Monetarism and Economic Development. The experience of Argentina 1976-1981', M Phil dissertation, University of Sussex

Cline, W., and S. Weintraub (eds), 1981, Economic Stabilis ation in Developing Countries, The Brookings Institution, Washington

Díaz Alejandro, C. F., 1965, Exchange-Rate Devaluation in a Semi-Industrialised Country: the Experience of Argentina 1955-1961, MIT Press, Cambridge, Mass

- 1970, Essays on the Economic History of the Argentine Republic, Yale University Press, New Haven

- 1981, 'Southern Cone stabilisation' in Economic Stabilisation in Developing Countries, W. Cline and S. Weintraub (eds)

Johnson, H., 1978, 'The monetary approach to the balance of payments theory', in J. Frenkel and $\mathrm{H}$. Johnson (eds) The Monetary Approach to the Balance of Payments

Kaldor, N., 1970, 'The new monetarism', reprinted in N. Kaldor, Further Essays on Applied Economics, Duckworth, 1978

-1980, 'Monetarism and UK monetary policy', Cambridge Journal of Economics, no 4

McKinnon, R., 1981, 'Comments on Díaz Alejandro and Kruegger,' in Economic Stabilisation in Developing Countries, W. Cline and $\mathrm{S}$. Weintraub (eds)

Sidrauski, M., 1968, 'Devaluación, inflación y desempleo,' Económica, no 1-2, enero-agosto 1968

Sourrouille, J., 1981, 'Política económica y procesos de desarrollo: Ia experiencia reciente de la Argentina', version preliminar, mimeo, Buenos Aires 